\title{
FEATURES OF EVALUATION OF THE COMPETITIVE STATUS OF TOURIST ENTERPRISES
}

\author{
Kyrylo MYKOLAYCHUK', Galina SAVINA² \\ Kherson National Technical University, Ukraine
}

\begin{abstract}
The purpose of the paper is to provide methodological approaches to assessing the competitive status of the tourism business at different levels of management and to determine the characteristics of models for tourism enterprises. The construction of models will allow identifying the factors, influencing the competitive position; will contribute to increasing the competitiveness of tourism business in the regions and countries. Methodology. The research is based on a comparison of the methods of assessing the competitiveness of countries and their achievements in sustainable development. Indicators of competitiveness characterize the preconditions of development, and achievements in the implementation of competitiveness can be estimated on the basis of competitive status. The main achievement of each country is to ensure sustainable development. A generalized assessment, positioning of states is based on the Human Development Index (HDI). It can be considered the main method of assessing the competitive status of the country. To assess the achievements of the regions in ensuring sustainable development, the regions of the HDI are determined, and appropriate indicators for enterprises can be developed. Such a system of assessment is also required for tourism business. Competitiveness of tourism activity of countries is assessed internationally by the index of competitiveness of travel and tourism (ICTT). Based on the comparison of the HDI and ICTT, it is advisable to develop an indicator of the competitive status of tourism business in the country, regions, and enterprises. Results. Among the components of $\mathrm{HDI}$, the most important is economic and social development. The impact of the tourism business on the economic component reflects the direct contribution to GDP of the country, as well as the indirect contribution by the cost of tourists in the territory of stay and investment in the development of tourism activities. One of the main social consequences of sustainable development is the increase in life expectancy. It is influenced by human confidence in the future, which depends on employment of the population. Accordingly, the contribution to employment of the population is divided into employment directly in the field of tourism and general employment, taking into account the use of labour suppliers of products and services in other fields of activity. In assessing the competitive status of the tourist business of the regions, statistical indicators should be used, which reflect the results of tourism activity and factors influencing them. The economic results are influenced by revenues from the provision of tourist services and the structure of tourist flows. The social component should take into account employment, education, and remuneration of the subjects of tourism activity. It is worth taking into account the proportion of women and young people. Methodological approaches to assessing the competitive status of tourism enterprises should be coordinated with the assessment of the competitive status of the tourism business in the region. Based on this, the indicator of the competitive status of a tourist enterprise (ICSTE) should also be determined by two components that characterize the impact on the economic and social development of the region. But in this indicator, it makes no sense to evaluate tourist flows, because they form integrated tourism services and distribute them mainly to different subjects of tourism activity. Practical implications. The results of the comparative assessment of the competitive status of the regions of Ukraine, as well as enterprises of the region, can reveal promising directions for the development of tourism business. Value/originality. The model of estimation of the competitive status of tourist enterprises as a component of the system of evaluation of achievements in the development of tourism business of the country and regions, which is proposed, has a scientific novelty and contributes to the increase of the positive influence of tourism enterprises on the sustainable development of regions and the country.
\end{abstract}

Key words: competitive status, country, regions, tourist enterprises, factors of influence, methods of evaluation.

JEL Classification: C52, O50, P25, Z31

Corresponding author:

${ }^{1}$ Department of Management and Marketing, Kherson National Technical University.

E-mail: mykmm@meta.ua

${ }^{2}$ Department of Management and Marketing, Kherson National Technical University.

E-mail: savinagalina28@gmail.com 


\section{Introduction}

The economy of Ukraine needs a structural adjustment, the priority of which is the development of services. The natural resource potential of Ukraine, unique features of individual regions create preconditions for the development of tourism activities. However, in recent years, there has been an intensification of competition in the tourism market that is strategically important for our country. Therefore, the introduction at the domestic tourist enterprises of the competitive management, the essence of which is to ensure their competitiveness, both in the domestic and foreign markets, becomes more and more relevant. Solving the problems of increasing competitiveness requires a clear definition of the essence of this category, systematization of methods for assessing the achievements of enterprises. Competitiveness is characterized by the ability to gain an edge in a competitive struggle, ahead of their rivals in achieving their goals in a competitive environment. However, it allows you to assess the preconditions for the development of tourism business but does not guarantee its high results. Achievements in the management of competitiveness can be estimated on the basis of competitive status, which reflects the presence of stable competitive advantages from enterprises and allows determining the positions in the competition. It should be noted that in the conditions of globalization, each country becomes a subject of management in the world space; it provides a certain contribution to solving global problems. The main task of the world economy is sustainable development. Undoubtedly, the world community needs to assess the state of affairs in ensuring sustainable development of each country in order to determine the overall achievements and problems of mankind, allowing countries to compare their achievements, to identify their strengths and weaknesses. Although each country and its regions form their own system for measuring the results, the criteria for sustainable development that they use should be consistent with those used by the international community in determining the various ratings. A generalized assessment of the achievements of each country in ensuring sustainable development, positioning of states is based on the Human Development Index (HDI), that is, this indicator reflects the competitive status of the country. In addition to HDI, internationally, competitive indices are used that measure the favourable conditions for achieving a high competitive status. The most common comprehensive indexes are: Global Competitiveness Index, World Competitiveness Index, Index of Ease of Business, Index of Economic Freedom. Along with the comprehensive indexes, specialized indexes are defined that characterize the favourable conditions and threats for the development of specific areas of activity: trade promotion index, network availability index, index of competitiveness of travel and tourism. However, the competitive status of certain types of activities is not determined. It is important to take into account that the entities of the generation, as achievements in sustainable development, and problems, are enterprises. Therefore, the Global Reporting Initiative (GRI) believes that it is precisely in the bottom line of the hierarchy of systems that provide sustainable development that it is necessary to systematically evaluate the results of various aspects of activity (Global Reporting Initiative, 2017). Then, the purpose of the study is to substantiate the methodological approaches to assessing the competitive status of the tourism business at different levels of management and to determine the characteristics of models for tourism enterprises. In order to control the competitive status of the tourism business of the country, its regions and tourism enterprises, the assessment model should reflect the HDI-approved criteria for assessing the results and the factors affecting competitiveness. Therefore, the purpose of the study is to substantiate the methodological approaches to assessing the competitive status of the tourism business at different levels of management and to determine the characteristics of models for tourism enterprises. Realization of the purpose needs comparing HDI with the Competitiveness Index of Travel and Tourism, developing, based on its results, indicators of the competitive status of tourism business of the country, regions, and enterprises, it is also advisable to assess the competitive status of tourist enterprises of one of the regions.

\section{Estimation of the competitive status of the tourist business of the country}

According to Human Development Report 2016 of United Nations Development Programme (United Nations Development Programme, 2016), Ukraine ranks 84th among 118 countries, and its results are lower than the average for countries in Europe and Central Asia. Economic achievements in the development of countries are estimated on the basis of the gross national product per capita (GNP), and social-based on the expected life expectancy and education of the population. The analysis of the components of national competitiveness based on the Global Competitiveness Index (World Economic Forum, 2015) helps to identify the economic transformations that are necessary for the sustainable growth. In order to assess the preconditions for the development of the tourism business and the organization of targeted work to increase the competitive status of tourism enterprises, the index of competitiveness of travel and tourism (ICTT) has a particular importance. Among the factors that can be influenced at all levels of management, it is worth allocating human resources. Among the factors that can be influenced at all levels of management, it is worth 
allocating human resources. To reconcile with the HDI index of the country's competitive status in the tourism business (ICSTB), it is expedient to determine it on the basis of two components that reflect the contribution of tourism activities to the country's economic and social development. The first component should reflect the direct and indirect contribution to GDP of the country (the cost of foreign tourists in the territory of stay, investments in the development of tourism activities). One of the criteria for the sustainable development is the increase in life expectancy, which is positively influenced by the confidence in the future, which depends on the employment of the population. Therefore, the second component of the indicator of the competitive status of the country in the tourism business should reflect the contribution to employment of the population, which is divided into employment directly in the field of tourism and employment, taking into account the use of labour suppliers of products and services in other fields of activity. We will assume that the importance of economic results should be greater because they have a positive impact on the social component, and high employment can indicate an insufficiently high efficiency at the use of personnel.

\section{Assessment of the competitive status of the tourist business of regions}

The overall results of the country are significantly influenced by the tourist activity of the regions. Therefore, it is necessary to assess the competitive status of the tourist business of the regions (ICSTBR). To do this, you should use statistical reporting indicators that reflect the results of tourism activities and the factors influencing them. By analogy with ICSTB, the definition of ICSTBR is accomplished through two components that characterize the contribution of tourism to the economic and social development of the region and the country. The contribution of tourist activity to GDP depends on the revenue from providing tourist services and the structure of tourist flows. The indicator of the structure has three components, the weight of which is not the same. It is desirable to increase the number of foreign tourists who spend considerable money during their stay in the country, and Ukrainian citizens traveling within the territory of Ukraine. The social component must take into account employment, education, and remuneration of the subjects of tourism activity. It should be borne in mind that since 2010, the HDI is determined on the basis of additional indicators - inequality of incomes, gender inequality and multidimensional poverty. It is advisable to reflect the involvement of young people. Therefore, the indicator has the following components: Employment of workers in the field of tourism; education of workers in the field of tourism activity; the share of labour costs in operating activities. The Employment Indicator has three components that reflect the overall employment, the share of women, and the share of workers under the age of 30 .

\section{Model of assessment of the competitive status of tourist enterprises}

The complexity and multidimensionality of the processes of meeting the needs of the person traveling turn tourism into the industry. Subjects of tourist activity according to the Law of Ukraine "On Tourism" (Verkhovna Rada of Ukraine, 2015) include: tourist operators, travel agents, other subjects of entrepreneurial activity, providing services for temporary accommodation, food, excursion services and others; specialists of tourist support (guidestranslators, sports instructors, directors, etc.), except for those who work on respective positions of enterprises, organizations, establishments that have visited objects or serve them, individuals who are not sub-entities' business activities but provide accommodation, catering, etc. Their role in providing tourist activities is different. Thus, individuals who are not business entities can only provide vacationers with accommodation or supplementary food provision. At the same time, they serve a small number of people who prefer an unorganized rest. Subjects of entrepreneurial activity mainly provide specialized services in accommodation, food or excursion service, at the same time, a certain number of tourists, which depends on the capabilities of their material base. Specialists of tourist support provide specialized services, which are ordered by business entities engaged in excursions, etc. Comprehensive services are offered by tour operators and travel agents. Tourist operators in accordance with the Law of Ukraine "On Tourism" (Verkhovna Rada of Ukraine, 2015) may be legal entities created in accordance with the legislation of Ukraine, obtained a license for tour operator activities, provide the formation of tourism product, its implementation and mediation activities for the provision of characteristic and related services. That is, the tour operators themselves are manufacturers of integrated tourist product. It is mainly distributed by natural persons-entrepreneurs - tour agents. There is no consensus among scholars as to subjects of the tourism. The author's vision is that tourist enterprises are legal entities created in accordance with the legislation of Ukraine, which form a complex tourist product, organize interaction with producers of certain tourist functions, perform intermediary functions in selling consumers of an integrated tourist product. Therefore, tour operators should be considered as tour operators.

Methodological approaches to assessing the competitive status of tourism enterprises should be coordinated with the assessment of the competitive status of the tourism business in the region. Based on this, the indicator of the competitive status of a tourist enterprise (ICSTE) should also be determined by 
two components that characterize the impact on the economic and social development of the region.

$$
\operatorname{ICSTE}=0,7 \mathrm{I}_{I E D}+0,3 \mathrm{I}_{I S D} \text {. }
$$

However, in assessing the economic component, it is necessary to limit the definition of the indicator of income from the provision of tourist services. That is,

$$
\mathrm{I}_{\text {IED }}=\mathrm{I}_{\text {ITS }} \text {. }
$$

Exceptions to the economic component of the characteristics of tourist flows are due to the fact that various subjects of the tourism industry mainly specialize in the servicing of domestic tourists or those traveling abroad. For example, in Kherson region in 2016, tour operators sold $93.6 \%$ of vouchers to Ukrainian citizens traveling within Ukraine and only 6.4\% for travel abroad (Chief Department of Statistics in Kherson Oblast, 2017). Travel agents mainly provide tours to those who prefer traveling abroad. For foreign tourists, the realization of permits was not carried out.

The social component should be identical to the analogous component of the indicator of the competitive status of the tourist business of the region and take into account employment (with the allocation of the proportion of women and youth), education, and the payment of labour by the subjects of tourism activity.

Therefore, the indicator of the social development of a tourist enterprise has the following components:

$$
\mathrm{I}_{I S D}=\frac{\mathrm{I}_{E m p}+\mathrm{I}_{E L}+\mathrm{I}_{L C}}{3} \text {, }
$$

$\mathrm{I}_{I S D}$ - Indicator of Impact on Social Development;

$\mathrm{I}_{\text {Emp }}$ - Employment Indicator;

$\mathrm{I}_{E L}$ - Indicator of Education of Labours of touristic enterprise;

$I_{L C}$ - Indicator of Labour Costs for a tourist enterprise.

The Employment Indicator has three components that reflect the overall employment, the share of women, and the share of workers under the age of 30 .

$$
\mathrm{I}_{E m p}=\frac{\mathrm{I}_{T e}+\mathrm{I}_{W o m}+\mathrm{I}_{Y W}}{3} \text {, }
$$

$\mathrm{I}_{\text {Emp }}-$ Employment Indicator;

$\mathrm{I}_{T e}$ - Total employment;

$\mathrm{I}_{\text {Wom }}$ - The share of women;

$\mathrm{I}_{Y W}$ - The share of workers under the age of 30 (young workers).

Unlike the methodology for calculating the Human Development Index proposed by the United Nations Development Program (UNDP), where the indicator value is defined as the ratio of the difference between the value of a country's indicator and the maximum value of this indicator to the extent of the variation of the indicator being analysed, we suggest using the relationship between the value of the index being analysed and the maximum value of the indicator. This will allow you to get a more "contrasting" feature.

$\mathrm{I}_{j}=\frac{\mathrm{X}_{j}}{\mathrm{X}_{\max }}$,

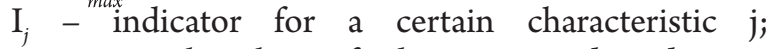

$\mathrm{x}_{j}$ - actual value of the estimated indicator;

$\mathrm{x}_{\max }$ - maximum value of the estimated indicator.

Thus, the indicators are measured within from 0 to 1 . A comparison of enterprises according to the system of indicators, characterizing their competitive advantages, will allow determining the integral relative estimation of competitive advantages. An approximation to 1 indicates a leading position in a particular area of activity.

\section{Competitive status of tourist enterprises of the Kherson region}

In the market of tourist services of the Kherson region in 2016, there were 3 tourist enterprises (tour operators): PE "XXI Vek Ukrainy" ("XXI century of Ukraine”), PE "Svitlana Tour" and "Tur Plaza" ("Tour Plaza"). The results of calculating the employment indicator (from the best to the worst) are given in Table 1 .

The highest level of employment indicator at PE "Svitlana Tour" is due to the structure of the labour force that meets the global requirements of sustainable development: gender policy and youth involvement.

Table 1

Components for the employment indicator

\begin{tabular}{|l|c|c|c|c|}
\hline \multicolumn{1}{|c|}{ Enterprise } & Total employment & The share of women & $\begin{array}{c}\text { The share of workers } \\
\text { under the age of 30. }\end{array}$ & Employment Indicator \\
\hline PE “Svitlana Tour" & 0,374 & 1 & 1 & 0,791 \\
\hline PE “XXI Vek Ukrainy" & 0,374 & 1 & - & 0,458 \\
\hline TOV “Tur Plaza" & 1 & - & - & 0,333 \\
\hline
\end{tabular}

Source: (results obtained by the authors on the basis of calculations)

Table 2

The structure of the social component of the indicator of the competitive status of the enterprise

\begin{tabular}{|l|c|c|c|c|}
\hline \multicolumn{1}{|c|}{ Enterprise } & Employment Indicator & Education Indicator & Indicator of Labour Costs & $\begin{array}{c}\text { Indicator of Impact on } \\
\text { Social Development }\end{array}$ \\
\hline PE “Svitlana Tour” & 0,791 & 1 & 0,990 & 0,927 \\
\hline PE “XXI Vek Ukrainy” & 0,458 & - & 1 & 0,486 \\
\hline TOV “Tur Plaza” & 0,333 & 0,499 & 0,039 & 0,289 \\
\hline
\end{tabular}

Source: (results obtained by the authors on the basis of calculations) 
This tourist operator has almost all employees under the age of 30 , including $50 \%$ of women.

The largest number of employees is at the Tur Plaza TOV but the lack of women and young people led to a low rating of the employment indicator. Table 2 shows the components of the indicator of the impact on social development.

According to this indicator, the ratio of the levels of the indicator also highlights the benefits of PE "Svitlana Tour", where the vast majority of employees (66.7\%) have higher or secondary special education in the field of tourism. The total values of the Indicator of the Competitive Status of Travel Enterprises (ICSTE) are shown in Table 3.

\section{Table 3}

Components of the Index of the Competitive Status of the Tourist Enterprise

\begin{tabular}{|l|c|c|c|}
\hline \multicolumn{1}{|c|}{ Enterprise } & $\begin{array}{c}\text { Indicator of } \\
\text { Impact on } \\
\text { Economic } \\
\text { Development }\end{array}$ & $\begin{array}{r}\text { Indicator } \\
\text { of Impact } \\
\text { on Social } \\
\text { Development }\end{array}$ & ICSTE \\
\hline $\begin{array}{l}\text { PE "XXI Vek } \\
\text { Ukrainy" }\end{array}$ & 0,007 & 0,486 & 0,151 \\
\hline TOV “Tur Plaza" & 1 & 0,289 & 0,786 \\
\hline PE "Svitlana Tour" & 0,011 & 0,927 & 0,286 \\
\hline
\end{tabular}

Source: (results obtained by the authors on the basis of calculations)

According to the general results, the highest level of competitive status is limited liability company "Tur Plaza". The main advantage of this company is in providing high economic results. When using the prospects of a prospective staffing, Private Enterprise
"Svitlana Tour" can strengthen its position in the market for tourist services in the region.

\section{Conclusions}

The growth of competition in the market of tourist services makes it necessary to carry out competitive management of the development of this sphere of activity. Its essence lies not only in increasing the competitiveness of the tourism industry but also in transforming the opportunities in the results obtained, which characterize the competitive status. The tourism business should positively influence the sustainable development of the country and its regions. Therefore, the criteria for assessing the competitive status of a tourism business must be consistent with the criteria for assessing the country's competitive status in the global community, which is an integral indicator of the HDI. In this regard, in models for assessing the competitive status of the tourist business of economic entities, it is expedient to identify the components that characterize the impact of the tourism business on economic and social development. The list of indicators for each component at the country, regional or enterprise level depends on the factors influencing their competitive status and the availability of official statistical reporting thereon. The results of the evaluation of the competitive status of tourism enterprises, which play a special role in ensuring the development of tourism activities, allow positioning enterprises in the market of tourist services of the regions, to identify ways to further improve the performance of their activities.

\section{References:}

Global Reporting Initiative (2017). GRI and Sustainability Reporting Web page. Retrieved from: https://www.globalreporting.org/information/sustainability-reporting/Pages/gri-standards.aspx

United Nations Development Programme (2016). Human Development Report 2016: Human Development for Everyone. Retrieved from: http://hdr.undp.org/sites/default/files/2016_human_development_report.pdf

World Economic Forum (2015). The Global Competitiveness Report 2016-2017 Web page. Retrieved from https://www.weforum.org/reports/the-global-competitiveness-report-2016-2017-1

Verkhovna Rada of Ukraine (2015). About Tourism (11.02.2015) Web page. Retrieved from: zakon3/rada/gov/ ua/laws/show/324/95-вp

Chief Department of Statistics in Kherson Oblast (2017). Recreation and tourism in the Kherson region. The statistical bulletin for 2016, Kherson

\section{Кирилл МИКОЛАЙЧУК, Галина САВИНА} ОСОБЕННОСТИ ОЦЕНИВАНИЯ КОНКУРЕНТНОГО СТАТУСА ТУРИСТИЧЕСКИХ КОМПАНИЙ

Аннотация. Целью исследования является обоснование методических подходов к оцениванию конкурентного статуса туристического бизнеса на разных уровнях управления и определение особенностей моделей для туристических предприятий. Построение моделей позволит выявить управляемые факторы влияния на конкурентный статус, способствовать повышению конкурентоспособности туристического бизнеса регионов и страны. Методология. Исследование основывается на сравнении методов оценивания конкурентоспособности стран и их достижений в устойчивом развитии. Индикаторы конкурентоспособности характеризуют предпосылки развития, а достижения в их реализации возможно оценить на основе показателей конкурентного статуса. Главным показателем развития каждой страны является обеспечение 
устойчивого развития. Обобщенная оценка, позиционирование государств, осуществляется на основе Индекса человеческого развития (ИЧР). Его можно считать основным методом оценивания конкурентного статуса страны. Для оценивания достижений регионов в обеспечении показателей устойчивого развития определяют ИЧР регионов, возможна разработка соответствующих индикаторов и для предприятий. Подобная система оценивания необходима и для туристического бизнеса. Конкурентоспособность туристической деятельности стран оценивается на международном уровне с помощью индекса конкурентоспособности путешествий и туризма (ИКПТ). На основе сопоставления ИЧР и ИКПТ целесообразно разработать индикатор конкурентного статуса туристического бизнеса страны, регионов, предприятий. Результаты. Среди составляющих ИЧР наибольшее значение имеют экономическое и социальное развитие. Влияние туристического бизнеса на экономическую составляющую отражает прямой вклад в валовый внутренний продукт страны, а также непрямой вклад путем расходов туристов на территории пребывания и инвестиций в развитие туристической деятельности. Одним из основных социальных результатов устойчивого развития является увеличение продолжительности жизни. На нее влияет уверенность человека в будущем, которая зависит от занятости населения. Соответственно и вклад в занятость населения подразделяется на занятость непосредственно в сфере туризма и общую занятость с учетом использования труда поставщиков продукции и услуг других сфер деятельности. При оценивании конкурентного статуса туристического бизнеса регионов следует использовать показатели статистической отчетности, которые отражают результаты туристической деятельности и управляемые факторы влияния на них. На экономические результаты влияют доходы от предоставления туристических услуг и структура туристических потоков. Социальная составляющая должна учитывать занятость, образование, оплату труда субъектами туристической деятельности. При этом целесообразно учитывать удельный вес женщин и молодежи. Методические подходы к оцениванию конкурентного статуса туристических предприятий должны быть согласованы с оцениванием конкурентного статуса туристического бизнеса региона. Исходя из этого, индикатор конкурентного статуса туристического бизнеса предприятия (ИКСТП) тоже следует определять на основе двух составляющих, которые характеризуют влияние на экономическое и социальное развитие. Однако, в этом индикаторе нет смысла оценивать туристические потоки, так как формируют комплексные туристические услуги и распространяют их в основном разные субъекты туристической деятельности. Практическоезначение. Результаты сравнительной оценки конкурентного статуса регионов Украины, а также предприятий региона, позволяют выявить перспективные направления развития туристического бизнеса. Значение/оригинальность. Предложенная модель оценивания конкурентного статуса туристических предприятий, как составляющая системы оценивания достижений в развитии туристического бизнеса страны и регионов, имеет научную новизну и способствует увеличению позитивного влияния туристических предприятий на устойчивое развитие регионов, страны в целом. 